\title{
Sigma-2 receptor ligand as a novel method for delivering a SMAC mimetic drug for treating ovarian cancer
}

\author{
C Zeng ${ }^{1,6}$, S Vangveravong ${ }^{1,6}$, J E McDunn ${ }^{2}$, W G Hawkins ${ }^{3}$ and R H Mach H,1,4,5 $^{*}$ \\ ${ }^{1}$ Division of Radiological Sciences, Department of Radiology, Washington University School of Medicine, St Louis, MO, USA; \\ ${ }^{2}$ Metabolon, Inc., Durham, NC, USA; ${ }^{3}$ Department of Surgery, Washington University School of Medicine, St Louis, MO, USA; \\ ${ }^{4}$ Department of Cell Biology and Physiology, Washington University School of Medicine, St Louis, MO, USA and ${ }^{5}$ Department of \\ Biochemistry and Molecular Biophysics, Washington University School of Medicine, St Louis, MO, USA
}

Background: The sigma-2 receptor has been validated as a biomarker for proliferating tumours. Second mitochondria-derived activator of caspase (Smac) is a protein released from mitochondria into the cytosol, leading to apoptosis. In this study, we investigated a sigma-2 ligand as a tumour-targeting drug delivery agent for treating ovarian cancer.

Methods: A sigma-2 ligand, SW 43, was conjugated with a Smac mimetic compound (SMC), SW IV-52s, to form SW III-123. The delivery function of the sigma-2 moiety and cell killing mechanisms of SW III-123 were examined in human ovarian cancer cell lines.

Results: SW III-123 internalisation into ovarian cancer cells was mediated by sigma-2 receptors. SW III-123, but not SW IV-52s or SW 43, exhibited potent cytotoxicity in human ovarian cancer cell lines SKOV-3, CaOV-3 and BG-1 after 24-h treatment, suggesting that the sigma-2 ligand successfully delivered SMC into ovarian cancer cells. SW III-123 induced rapid degradation of inhibitor of apoptosis proteins (CIAP1 and cIAP2), accumulation of NF- $\kappa$ B-inducing kinase (NIK) and phosphorylation of NF- $\kappa$ B p65, suggesting that SW III-123 activated both canonical and noncanonical NF- $\kappa$ B pathways in SKOV-3 cells. SW III-123 cleaved caspase-8, -9 and -3. Tumour necrosis factor alpha (TNF $\alpha$ ) antibody markedly blocked SW III-123-induced cell death and caspase-3 activity in SKOV-3 cells, indicating that SW III-123 activated both intrinsic and extrinsic apoptotic pathways and induced TNF $\alpha$-dependent cell death in SKOV-3 cells.

Conclusion: Sigma-2 ligands are a promising tumour-targeting drug delivery agent. Sigma-2-conjugated SMC exemplifies a novel class of therapeutic drugs for treating ovarian cancer.

Ovarian cancer is the leading cause of death from gynaecological malignancies, with approximately 21550 new cases and 14600 deaths occurring annually in the United States (Jemal et al, 2009). Over the past two decades, the first-line chemotherapeutic drugs for treating epithelial ovarian cancer have been the platinum-based drug cisplatin and taxanes such as paclitaxel (Stordal et al, 2007; Dinh et al, 2008). Most patients respond well initially to platinum and taxane-based therapies, unfortunately resistance frequently ensues. Moreover, the major limitation of conventional chemotherapy is severe toxicity to normal tissues resulting from a lack of selectivity towards cancer cells. Thus, cancer-selective targeting has been recognised as an important goal in developing new therapeutics (Torchilin, 2010).

In this study, we used a new strategy to deliver anticancer drugs selectively into ovarian tumour cells by targeting sigma- 2 receptors. The sigma-2 receptor is overexpressed in various human tumours (Bem et al, 1991; Vilner and Bowen, 1993; Vilner et al, 1995). Our group has previously validated the sigma-2 receptor as a biomarker

*Correspondence: Dr RH Mach; E-mail: rmach@mail.med.upenn.edu
${ }^{6}$ These authors contributed equally to this work. 
for imaging proliferating tumour cells (Mach et al, 1997; Wheeler et $a l, 2000)$. The density of sigma-2 receptors in proliferative tumour cells is approximately 10 -fold higher than in nonproliferative or quiescent tumour cells in cell culture and in solid tumours. Sigma-2 receptor-selective radiotracers, developed in our laboratory, have been shown to target various solid tumours in rodents and in human patients using the functional imaging technique, positron emission tomography (PET), and the uptake of the sigma-2-selective radiotracer $\left[{ }^{18} \mathrm{~F}\right] \mathrm{ISO}-1$ correlated with the Ki-67 score in lymphoma, head and neck, and breast cancer patients (Tu et al, 2005, 2007; Dehdashti et al, 2013). These data demonstrate that sigma-2 receptor ligands possess high selectivity for tumour cells vs normal tissues in vivo. In addition, we have previously demonstrated that the fluorescent sigma-2 receptor probe, SW 120, is rapidly internalised into cancer cells by an endocytotic pathway and localises in multiple subcellular organelles such as mitochondria and endoplasmic reticulum (Zeng et al, 2007, 2011), suggesting that sigma-2 receptor ligands are excellent candidates to deliver anticancer drugs selectively into tumours. This sigma- 2 receptor-targeting strategy has shown the initial success in pancreatic tumour xenograft mouse models (Spitzer et al, 2012). Recently, our group has identified progesterone receptor membrane component 1 as the potential sigma-2 receptor (Xu et al, 2011). This finding will facilitate further investigations of sigma-2 receptor-selective ligands for imaging, therapeutic and drug delivery applications.

Second mitochondria-derived activator of caspase (Smac) is a protein released from mitochondria into the cytosol in response to apoptotic stimuli (Du et al, 2000; Shiozaki and Shi, 2004). Smac protein promotes apoptosis through binding to and antagonising the activity of inhibitor of apoptosis proteins (IAPs) including XIAP, cIAP-1 and cIAP-2, thus relieving them of their caspasebinding partners and sensitising cells to apoptosis. XIAP binds and inhibits caspase- 9 through its baculovirus IAP repeat (BIR) 3 domain and caspase-3/7 through its BIR2 domain together with the linker before BIR2. Smac interacts with the BIR2 or BIR3 domain of IAPs via the AVPI tetrapeptide-binding motif on the $\mathrm{N}$-terminus of Smac. Small-molecule Smac mimetic compounds (SMC) have been developed by imitating the AVPI-binding motif of Smac (Sun et al, 2008). SMC have been shown to sensitise tumour cells to other anticancer drugs as well as to induce apoptosis as single agents in a subset of tumour cells (Petersen et al, 2007; Petrucci et al, 2007; Varfolomeev et al, 2007; Vince et al, 2007; Sun et al, 2008; Wang, 2011; Petrucci et al, 2012). SMC have been introduced in phase I clinical trials (Gyrd-Hansen and Meier, 2010). However, a recent report indicated that SMC can increase tumour metastasis in the bone via osteoclast activation (Yang et al, 2013). Therefore, it is important that SMC is delivered specifically into tumour cells rather than normal tissues such as bone. In this study, we aimed to use a sigma-2 ligand to deliver SMC into ovarian cancer cells. We have conjugated a sigma-2 ligand, SW 43, to a SMC, SW IV-52s, to form a sigma-2 receptor ligand-conjugated SMC, SW III-123. We have shown that the sigma-2 ligand effectively delivers SMC into ovarian cancer cells and potently induces cell death. SW III-123 induced degradation of cIAP1 and cIAP2, NF- $\kappa$ B activation, and tumour necrosis factor alpha (TNF $\alpha$ )-dependent apoptosis in SKOV-3 cells, likely representing a novel class of therapeutic drugs for treating ovarian cancer.

\section{MATERIALS AND METHODS}

Chemical synthesis of SW III-123 and SW IV-52s. ${ }^{1} \mathrm{H}$ NMR spectra were recorded on a Varian $300 \mathrm{MHz}$ NMR spectrometer (Varian, Inc., Walnut Creek, CA, USA). Chemical shifts are reported in $\delta$ values (parts per million) relative to an internal standard of tetramethylsilane. The following abbreviations are used for multiplicity of NMR signals: br $\mathrm{s}=$ broad singlet, $\mathrm{d}=$ doublet, $\mathrm{m}=$ multiplet, $\mathrm{s}=$ singlet. Melting points were determined on an electrothermal melting point apparatus and are uncorrected. Elemental analyses were performed by Atlantic Microlab, Inc., Norcross, GA, USA and were within $\pm 0.4 \%$ of the calculated values. Mass spectrometry was provided by the Washington University Mass Spectrometry Resource (Washington University, St Louis, MO, USA). All reactions were carried out under an inert atmosphere of nitrogen.

General procedure for peptide coupling. 1-Ethyl-3-(3-dimethylaminopropyl)carbodiimide (EDCI; $1.1 \mathrm{eq}$ ) was added to a stirred solution of the Boc-protected amino acid, N,N-diisopropylethylamine (DIPEA; $1.1 \mathrm{eq}$ ) and 1-hydroxybenzotriazole (HOBt; $1.1 \mathrm{eq})$ in DMF $(15 \mathrm{ml})$ at $0{ }^{\circ} \mathrm{C}$. After $5 \mathrm{~min}$, the amino component $(1.1 \mathrm{eq})$ was added to the ice-cold solution, and the reaction mixture was stirred overnight at room temperature. The mixture was diluted with EtOAc and washed with $2 \% \mathrm{HCl}$ solution, saturated $\mathrm{NaHCO}_{3}$ solution and brine, respectively. The organic layer was dried over $\mathrm{Na}_{2} \mathrm{SO}_{4}$, and the volatiles were removed under reduced pressure. The Boc-protected coupling product was purified by column chromatography (silica gel, EtOAc: hexane $=1: 2$ ).

General procedure for removal of the Boc-protecting group. The Boc-protected compound was stirred with trifluoroacetic acid in dichloromethane $(1: 2)$ for $5 \mathrm{~h}$ at room temperature. The volatiles were removed under reduced pressure, and the residue was basified with saturated $\mathrm{Na}_{2} \mathrm{CO}_{3}$ solution, extracted with dichloromethane, dried over $\mathrm{Na}_{2} \mathrm{SO}_{4}$, filtered and evaporated to give the product.

(S)-N-((R)-1,2,3,4-tetrahydronaphthalen-1-yl)pyrrolidine-2-carboxamide (3). Using the general procedure for peptide coupling and Boc removal, compound 3 was synthesised from Boc-proline (Pro)-OH (1) and R-(-)-1,2,3,4-tetrahydro-1-napthylamine (2) as an off-white powder $\left(83 \%\right.$ yield), mp $81-82{ }^{\circ} \mathrm{C}$. ${ }^{1} \mathrm{H}$ NMR $\left(\mathrm{CDCl}_{3}\right)$ $\delta 7.90(\mathrm{~d}, J=8.8 \mathrm{~Hz}, 1 \mathrm{H}), 7.09-7.17(\mathrm{~m}, 4 \mathrm{H}), 5.10-5.16(\mathrm{~m}, 1 \mathrm{H})$, 3.28-3.87 (m, 1H), 2.97-3.02 (m, 1H), 2.73-2.90 (m, 4H), 1.98-2.21 (m, 3H), 1.70-1.87 (m, 5H).

(S)-1-((S)-2-amino-3,3-dimethylbutanoyl)-N-((R)-1,2,3,4-tetrahydronaphthalen-1-yl) pyrrolidine-2-carboxamide (4). Using the general procedure for peptide coupling and Boc removal, compound $\mathbf{4}$ was synthesised from $\mathbf{3}$ and Boc-tert-leucine/ tert-butylglycine (Tle)-OH as an off-white solid (78\% yield), $\mathrm{mp}$ 143-144 ${ }^{\circ} \mathrm{C} .{ }^{1} \mathrm{H}$ NMR $\left(\mathrm{CDCl}_{3}\right) \delta 7.41(\mathrm{~d}, J=8.5 \mathrm{~Hz}, 1 \mathrm{H}), 7.04-7.21$ $(\mathrm{m}, 4 \mathrm{H}), 5.09-5.14(\mathrm{~m}, 1 \mathrm{H}), 4.63-4.66(\mathrm{~m}, 1 \mathrm{H}), 3.55-3.60(\mathrm{~m}, 2 \mathrm{H})$, 2.73-2.80 (m, 2H), 2.47-2.54 (m, 1H), 2.11-2.17 (m, 1H), 1.80-2.01 (m, 7H), 1.51 (br s, 2H), $0.80(\mathrm{~s}, 9 \mathrm{H})$.

(2S)-1-((2S)-2(2-chloropropanamido)-3,3-dimethylbutanoyl)$N$-((R)-1,2,3,4-tetrahydro-naphthalen-1-yl)pyrrolidine-2-carboxamide (5). A mixture of compound 4, 2-chloropropionyl chloride (1.2 eq) and triethylamine (3 eq) in dichloromethane $(15 \mathrm{ml})$ was stirred at room temperature for $4 \mathrm{~h}$, followed by adding saturated aqueous $\mathrm{NaHCO}_{3}$ and stirred for $30 \mathrm{~min}$. The organic layer was separated and evaporated. The resulting residue was purified by column chromatography (5\% methanol in dichloromethane) to give 5 as a light yellow solid ( $81 \%$ yield), mp $158-159{ }^{\circ} \mathrm{C} .{ }^{1} \mathrm{H}$ NMR $\left(\mathrm{CDCl}_{3}\right) \delta$ 7.22-7.25 (m, $\left.1 \mathrm{H}\right), 7.04-7.16(\mathrm{~m}, 4 \mathrm{H}), \quad 5.10-5.16$ $(\mathrm{m}, 1 \mathrm{H}), 4.55-4.61(\mathrm{~m}, 2 \mathrm{H}), 4.34-4.46(\mathrm{~m}, 1 \mathrm{H}), 3.63-3.76(\mathrm{~m}, 2 \mathrm{H})$, $2.73-2.80(\mathrm{~m}, 2 \mathrm{H}), 2.42-2.48(\mathrm{~m}, 1 \mathrm{H}), 1.83-2.17(\mathrm{~m}, 7 \mathrm{H})$, $1.69-1.73(\mathrm{~m}, 3 \mathrm{H}), 0.86(\mathrm{~s}, 9 \mathrm{H})$.

9-(10)((-1-(((S)-3,3-dimethyl-1-oxo-1-((S)-2-(((R)-1,2,3,4-tetrahydronaphthalen-1-yl) carbamoyl)pyrrolidin-1-yl)butan-2-yl)amino)1-oxopropan-2-yl)amino)decyl)-9-azabicyclo [3.3.1]nonan-3-yl (2-methoxy-5-methylphenyl) carbamate (SW III-123). A mixture of SW43 (350 mg, $0.8 \mathrm{mmol}), 5$ (340 $\mathrm{mg}, 0.8 \mathrm{mmol}$ ) and triethylamine 
(230 mg, $2.3 \mathrm{mmol})$ in THF $(7 \mathrm{ml})$ was heated at $65-70{ }^{\circ} \mathrm{C}$ for 6 days and evaporated. The resulting residue was purified by column chromatography ( $8 \%$ methanol in dichloromethane) to give SW III-123 as an off-white powder (137 mg, $31 \%$ yield), mp $66-67^{\circ} \mathrm{C}$. ${ }^{1} \mathrm{H}$ NMR $\left(\mathrm{CDCl}_{3}\right) \delta$ 7.89-7.95 (m, 2H), 7.22-7.29 (m, 2H), 7.04-7.14 (m, 4H), 6.73-6.80 (m, 2H), 5.10-5.18 (m, 2H), 4.52-4.61 $(\mathrm{m}, 2 \mathrm{H}), 3.85(\mathrm{~s}, 3 \mathrm{H}), 3.77-3.82(\mathrm{~m}, 1 \mathrm{H}), 3.59-3.66(\mathrm{~m}, 1 \mathrm{H})$, 3.09-3.16 (m, 3H), 2.44-2.79 (m, 9H), $2.30(\mathrm{~s}, 3 \mathrm{H}), 1.81-2.20$ $(\mathrm{m}, 9 \mathrm{H}), 1.27-1.62(\mathrm{~m}, 23 \mathrm{H}), 1.24(\mathrm{~d}, J=6.9 \mathrm{~Hz}, 3 \mathrm{H}), 0.85(\mathrm{~s}, 9 \mathrm{H})$.

(S)-1-((S)-3,3-dimethyl-2-((S)-2-(methylamino)propanamido) butanoyl)-N-((R)-1,2,3,4-terahydronaphthalen-1-yl)pyrrolidine2-carboxamide oxalate ( $S W I V-52 S$ ). Using the general procedure for peptide coupling from 4 and Boc- $\mathrm{N}$-Me-alanine (Ala)-OH, followed by Boc removal gave the product as a free amine (55\% yield). ${ }^{1} \mathrm{H}$ NMR $\left(\mathrm{CDCl}_{3}\right) \delta 7.74(\mathrm{~d}, J=9.8 \mathrm{~Hz}, 1 \mathrm{H}), 7.22-7.24$ (m, 2H), 7.04-7.14 (m, 3H), 5.12-5.14 (m, 1H), 4.58-4.61 (m, 1H), $4.55(\mathrm{~d}, J=9.8 \mathrm{~Hz}, 1 \mathrm{H}), 3.79-3.84(\mathrm{~m}, 1 \mathrm{H}), 3.64-3.67(\mathrm{~m}, 1 \mathrm{H})$, 3.05-3.07 (m, 1H), 2.73-2.79 (m, 2H), 2.43-2.47 (m, 1H), 2.34 (s, 3H), 2.10-2.18 (m, 1H), 1.95-2.01 (m, 2H), 1.82-1.89 (m, 4H), 1.56 (br s, $1 \mathrm{H}), 1.28(\mathrm{~d}, J=7.1 \mathrm{~Hz}, 3 \mathrm{H}), 0.85$ (s, 9H). The oxalate salt was prepared using 1 equivalent of oxalic acid in ethanol to give SW IV-52s as a light yellow solid, mp $148-149^{\circ} \mathrm{C}$. MS $m / z=443(\mathrm{M}+\mathrm{H})^{+}$. HRMS for $\left[\mathrm{C}_{25} \mathrm{H}_{39} \mathrm{~N}_{4} \mathrm{O}_{3}\right]^{+}$443.3022; found: 443.3038. Anal. $\left(\mathrm{C}_{27} \mathrm{H}_{40} \mathrm{~N}_{4} \mathrm{O}_{7}, 0.5 \mathrm{H}_{2} \mathrm{O}\right)$ : calculated, \%: C 59.87; H 7.63; N 10.34; found, \%: C 59.54, H 7.45, N 10.18.

Receptor-binding assays. The sigma-1 and sigma-2 receptorbinding affinities of SW III-123 were determined as previously described (Xu et al, 2005). Briefly, guinea pig brain (sigma-1 assay) or rat liver (sigma-2 assay) membrane homogenates ( $~ 300 \mu$ g protein) were diluted with $50 \mathrm{~mm}$ Tris- $\mathrm{HCl}, \mathrm{pH} 8.0$ and incubated with either $\sim 5 \mathrm{nM}\left[{ }^{3} \mathrm{H}\right](+)$-pentazocine (34.9 $\mathrm{Ci} \mathrm{mmol}^{-1}$; sigma-1 assay) or $1 \mathrm{nM}$ $\left[{ }^{3} \mathrm{H}\right] \mathrm{RHM}-1$ (80 $\mathrm{Ci} \mathrm{mmol}^{-1}$; sigma-2 assay) in a total volume of $150 \mu \mathrm{l}$ in 96-well plates at $25^{\circ} \mathrm{C}$. The concentrations of SW III-123 ranged from $0.1 \mathrm{~nm}$ to $10 \mu \mathrm{M}$. After incubating for $60 \mathrm{~min}$, the reactions were terminated by the addition of $150 \mu \mathrm{l}$ of cold wash buffer $(10 \mathrm{~mm}$ Tris-HCl, $150 \mathrm{~mm} \mathrm{NaCl}, \mathrm{pH}$ 7.4) using a 96-channel transfer pipette (Fisher Scientific, Pittsburgh, PA, USA), and the samples harvested and filtered rapidly into a 96-well fiberglass filter plate (Millipore, Billerica, MA, USA) that had been presoaked with $100 \mu \mathrm{l}$ of $50 \mathrm{~mm}$ Tris- $\mathrm{HCl}$, at $\mathrm{pH} 8.0$ for $1 \mathrm{~h}$. Each filter was washed three times with $200 \mu \mathrm{l}$ of ice-cold wash buffer, and the bound radioactivity quantified using a Wallac 1450 MicroBeta liquid scintillation counter (Perkin Elmer, Boston, MA, USA). Nonspecific binding was determined in the presence of $10 \mu \mathrm{M}$ cold haloperidol.

Cell culture conditions. The SKOV-3 human ovarian cancer cell line was cultured in 5A McCoy's medium containing $10 \%$ fetal bovine serum (FBS), $2 \mathrm{~mm}$ L-glutamine, and 100 units $\mathrm{ml}^{-1}$ penicillin and $100 \mu \mathrm{g} \mathrm{ml}^{-1}$ streptomycin. The CaOV-3 human ovarian cancer cell line was cultured in DMEM containing 10\% FBS, $2 \mathrm{~mm}$ L-glutamine, 100 units $\mathrm{ml}^{-1}$ penicillin and $100 \mu \mathrm{g} \mathrm{ml}^{-1}$ streptomycin. The BG-1 human ovarian cancer cell line was cultured in DMEM/F-12 containing $10 \% \mathrm{FBS}, 2 \mathrm{~mm}$ L-glutamine, 100 units $^{-1}$ penicillin and $100 \mu \mathrm{g} \mathrm{ml}^{-1}$ streptomycin. Cells were maintained in a humidified incubator at $37^{\circ} \mathrm{C}$ in a $5 \% \mathrm{CO}_{2}$ atmosphere.

MTS cell proliferation assay. The cytotoxicity of the compounds on SKOV-3, CaOV-3 and BG-1 human ovarian cancer cell lines was measured by the MTS assay. The MTS assay was performed using the CellTiter 96 Aqueous One Solution Assay (Promega, Madison, WI, USA) which contains a tetrazolium compound [3-(4,5-dimethylthiazol-2-yl)-5-(3-carboxymethoxyphenyl)-2-(4sulfophenyl)-2H-tetrazolium, inner salt; MTS], according to the manufacturer's protocol. Briefly, cells were plated $4 \times 10^{3}$ cells per well in 96-well plates $24 \mathrm{~h}$ before treatment with the compounds. Each compound was dissolved in DMSO and serially diluted in culture medium to acquire the desired concentrations. The final concentration of DMSO in the cell culture medium was no more than $1.0 \%$. After a 24 - or 48 -h treatment with the various compounds, $20 \mu \mathrm{l}$ of the CellTiter 96 aqueous one solution reagent was added to each well, and the plate was incubated for $1-2 \mathrm{~h}$ at $37^{\circ} \mathrm{C}$. The plate was then read at $490 \mathrm{~nm}$ in a Victor ${ }^{3}$ plate reader (PerkinElmer Life and Analytical Sciences, Shelton, CT, USA). The $\mathrm{EC}_{50}$, defined as the concentration of the sigma ligand required to inhibit cell proliferation by $50 \%$ relative to untreated cells, was determined from the dose-response curves generated using GraFit software, version 5 (Erithacus Software Limited, West Sussex, UK). All the compounds were assayed in triplicate, and the $\mathrm{EC}_{50}$ values presented as the mean \pm s.e.m. of three independent experiments.

Caspase-3 cell assay. The caspase- 3 activity induced by the compounds in SKOV-3 cells was measured using the Apo-ONE Homogeneous Caspase-3/7 Assay (Promega). This assay utilises a profluorescent substrate Z-DEVD-R110 specific for caspase-3/7 coupled with an optimised cell permeabilisation buffer. Cleavage of the peptide sequence DEVD by active caspase- $3 / 7$ releases free Rhodamine 110, which when excited at $485 \mathrm{~nm}$, becomes intensely fluorescent and can be detected at emission wavelength $535 \mathrm{~nm}$. The amount of fluorescent product generated is directly proportional to the caspase- $3 / 7$ activity in each sample. SKOV-3 cells were plated $4 \times 10^{3}$ cells per well in 96-well black, clear-bottomed plates $24 \mathrm{~h}$ before treatment with the compounds. After a $24-\mathrm{h}$ treatment with the various compounds, caspase-3 activity was assessed using the Apo-ONE Homogeneous Caspase-3/7 Assay. In all, $10 \mathrm{ml}$ of buffer was pre-mixed with $100 \mu \mathrm{l}$ of the caspase-3/7 substrate Z-DEVD-R110. In total, $100 \mu$ l of the substrate-buffer mix was added to each well and the plate was placed on an orbital shaker for $5 \mathrm{~min}$. The plate was then incubated at room temperature in the dark for up to $18 \mathrm{~h}$. The plate was then read at excitation and emission wavelengths 485 and $535 \mathrm{~nm}$, respectively, on a Victor ${ }^{3}$ plate reader (PerkinElmer Life and Analytical Sciences). Caspase-3 activation was determined by comparing maximal response values with untreated controls and results were plotted as increase over baseline.

Blocking studies of internalisation of SW 120 in SKOV-3 cells. SKOV-3 cells were plated in $100 \mathrm{~mm}$ dishes at $5 \times 10^{5}$ cells per dish for $24 \mathrm{~h}$ before treatment with compounds. The cells were incubated with $0,0.3,1,3$ and $10 \mu \mathrm{M}$ SW 43, SW IV-52s or SW III123 for $30 \mathrm{~min}$ at $37^{\circ} \mathrm{C}$. In all, $10 \mathrm{~nm}$ SW 120 was then added to the cell culture dishes containing the above blocking compounds. After 30 -min incubation at $37^{\circ} \mathrm{C}$, the cells were washed with phosphate-buffered saline (PBS) twice and detached with $0.05 \%$ trypsin-EDTA (Life Technologies, Grand Island, NY, USA). The cells were centrifuged at $1000 \times \mathbf{g}$ for $5 \mathrm{~min}$. The cell pellets were washed with PBS twice. Internalisation of SW 120 into the cells was analysed by flow cytometer. Flow Cytometric analysis was performed using a FACScan DxP10 (BD Bioscience, San Jose, CA, USA, and Cytek Development, Fremont, CA, USA), equipped with a $30 \mathrm{~mW}$ Coherent Sapphire solid state $488 \mathrm{~nm}$ laser to excite SW 120. Emission was captured with a $530 / 30$ bandpass filter.

Western blot analysis. SKOV-3 cells $\left(1 \times 10^{6}\right.$ per dish $)$ were plated in $100 \mathrm{~mm}$ culture dishes $24 \mathrm{~h}$ before drug treatment. For dose-response experiments, cells were treated with $0,1,3$ or $10 \mu \mathrm{M}$ SW 43, SW IV-52s or SW III-123 for $24 \mathrm{~h}$. For time course experiments, cells were treated with $3 \mu \mathrm{M}$ SW 43, SW IV-52s or SW III-123 for $0,0.5,2,6$ or $24 \mathrm{~h}$. The cells were then harvested and lysed in radioimmunoprecipitation assay buffer $(50 \mathrm{~mm}$ Tris, $150 \mathrm{~mm}$ sodium chloride, $1.0 \mathrm{~mm}$ EDTA, $1 \%$ Nonidet P40, and $0.25 \%$ SDS ( $\mathrm{pH} 7.0)$ ), supplemented with complete protease inhibitor cocktail (Roche, Mannheim, Germany) and phosphatase inhibitor cocktail 1 (Sigma Chemical Co., St Louis, MO, USA). The cells were sonicated briefly, centrifuged at $13000 \times \mathbf{g}$ for $20 \mathrm{~min}$ at 
$4{ }^{\circ} \mathrm{C}$, and the supernatant collected. The protein concentration was determined using a Bio-Rad Dc protein assay kit (Bio-Rad Laboratories, Hercules, CA, USA). Lysates containing $30 \mu \mathrm{g}$ of protein were run on a $12 \%$ acrylamide gel and transferred to a PVDF membrane (Bio-Rad Laboratories). The PVDF membrane was incubated with $5 \%$ nonfat dry milk for $1 \mathrm{~h}$ at room temperature, then overnight with a primary antibody at $4{ }^{\circ} \mathrm{C}$, and finally with the secondary antibody, horseradish peroxidase (HRP)-conjugated IgG. The SuperSignal West Pico Chemiluminescent Substrate assay kit (Pierce Biotechnology, Inc., Rockford, IL, USA) was used to detect the secondary antibody. For stripping western blots, the blot was incubated with stripping buffer (Pierce Biotechnology Inc.) for $15 \mathrm{~min}$ at room temperature.

Rabbit antibodies of caspase-3, caspase-9, XIAP, NIK, NF- $\kappa$ B p65, phospho-NF- $\kappa$ B p65 (Ser536), actin and mouse antibody of caspase-8 were purchased from Cell Signaling Technology (Danvers, MA, USA). The goat antibody of cIAP1 and the mouse antibody of cIAP2 were from R\&D Systems (Minneapolis, MN, USA). All the primary antibodies were used at a dilution recommended by the manufacturer. The secondary antibody was HRP-conjugated goat anti-rabbit IgG, HRP-conjugated horse antimouse IgG (Cell Signaling Technology) or HRP-conjugated rabbit anti-goat IgG (R\&D Systems) at a $1: 3000,1: 10000$ or $1: 1000$ dilution, respectively.

Statistical analysis. The results are expressed as the mean \pm s.e.m. based on three independent experiments performed in triplicate.
Differences among groups were statistically analysed using a twotailed Student's $t$-test. A $P$-value of $<0.05$ was considered significant.

\section{RESULTS}

Synthesis of SW IV-52s and SW III-123. The syntheses of SW III-123 and SW IV-52s (Oost et al, 2004; Sun et al, 2008) were outlined in Figure 1. Condensation of commercially available Boc-Pro-OH (1) and R-(-)-1,2,3,4-tetrahydro-1-nathylamine (2) in the presence of EDCI, DIPEA and HOBt, followed by removal of the Boc-protecting group gave 3 . Condensation of 3 with Boc-Tle-OH, followed by removal of the Boc-protecting group gave 4. Alkylation of $\mathbf{4}$ with 2 -chloropropionyl chloride gave $\mathbf{5}$. Reaction of 5 with amine SW 43 (Vangveravong et al, 2006) gave the desired product SW III-123 in 16\% yield (overall). Condensation of $\mathbf{4}$ with Boc- $\mathrm{N}-\mathrm{Me}-\mathrm{Ala}-\mathrm{OH}$ and removal of the Boc-protecting group gave SW IV-52s in 36\% yield (overall). SW III-123 has adequate sigma-2 receptor-binding affinity $\left(K_{i, \sigma 2}=189.90 \pm 12.84 \mathrm{~nm}\right)$, whereas it has low sigma-1 receptor-binding affinity $\left(K_{i, \sigma 1}=2046.30 \pm 62.62 \mathrm{nM}\right)$.

SW III-123 potently induced cell death in ovarian cancer cells. SKOV-3 cells were treated with increasing doses of SW 43, SW IV-52s, a combination of SW 43 and SW IV-52s or SW III-123

A

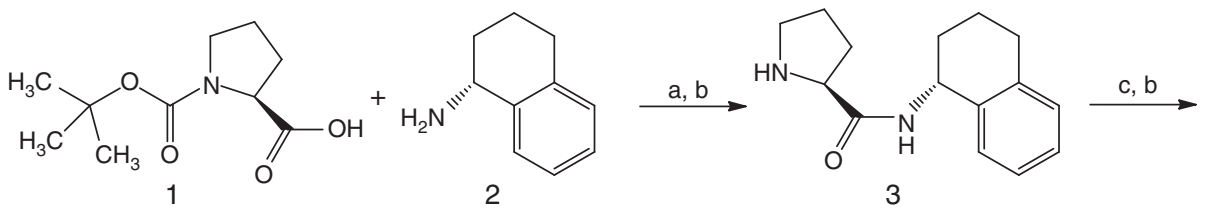<smiles>Cc1ccccc1[C@H]1CCCc2ccccc21</smiles>
5<smiles>COc1ccc(C)cc1NC(=O)OC1CC2CCC(C1)N2CCCCCCNC(C)C(=O)N[C@H](C(=O)N1CCC[C@H]1C(=O)N[C@H]1CCCc2ccccc21)C(C)(C)C</smiles>

Reagents: (a) EDCI, DIPEA, HOBt, DMF; (b) TFA, $\mathrm{CH}_{2} \mathrm{Cl}_{2}$ : (c) Boc-Tle-OH, EDCI, DIPEA, HOBt, DMF; (d) 2-chloropropionyl chloride, $\left(\mathrm{CH}_{3} \mathrm{CH}_{2}\right)_{3} \mathrm{~N}, \mathrm{CH}_{2} \mathrm{Cl}_{2}$; (e) SW43, $\mathrm{K}_{2} \mathrm{CO}_{3}, \mathrm{KI}, \mathrm{CH}_{3} \mathrm{CN}$, heat<smiles>COc1ccc(C)cc1NC(=O)OC1CC2CCCC(C1)N2CCCCCCN</smiles>

B

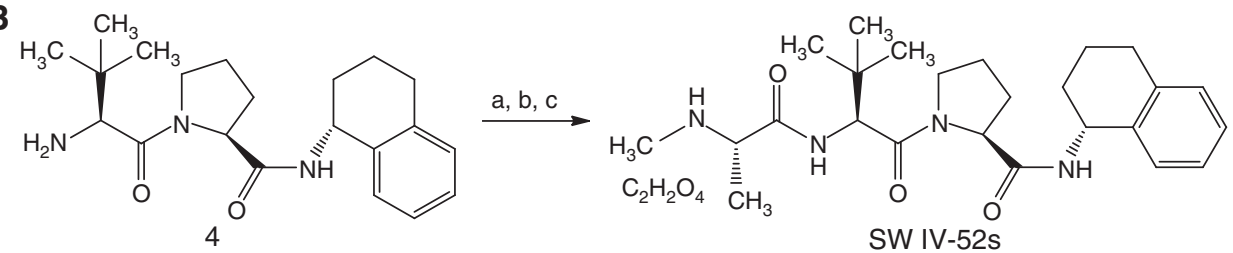

Reagents: (a) Boc-N-Me-Ala-OH, EDCI, DIPEA, HOBt, DMF; (b) TFA, $\mathrm{CH}_{2} \mathrm{Cl}_{2}$; (c) oxalic acid, EtOH.

Figure 1. The synthetic schemes for generating SW III-123 (A) and SW IV-52s (B). 
for $24 \mathrm{~h}, \mathrm{MTS}$ assay were performed to measure the cytotoxicity of these compounds. The results showed that SW III-123-induced cell death potently $\left(\mathrm{EC}_{50}=4.0 \mu \mathrm{M}\right)$ after 24 -h treatment, whereas SW 43, SW IV-52s, or a combination of SW 43 and SW IV-52s significantly shifted the dose-response curve rightward (Figure 2A). SW 43 showed cytotoxic effects but at higher doses than SW III-123. SW IV-52s showed minor cytotoxicity after 24-h treatment $\left(\mathrm{EC}_{50}>100 \mu \mathrm{M}\right)$, but exhibited potent cytotoxicity after 48 -h treatment $\left(\mathrm{EC}_{50}=0.7 \mu \mathrm{M}\right)$ in SKOV-3 cells (Table 1 and Supplementary Figure 1). The results suggest that SW IV-52s does not penetrate cells efficiently during 24-h treatment and the sigma-2 moiety in SW III-123 delivers the SMC moiety into SKOV -3 cells effectively.

Viability assays were also performed in two other human ovarian cancer cell lines, CaOV-3 and BG-1 (Figures 2B and C, and Supplementary Figure 1). The $\mathrm{EC}_{50}$ values for these compounds in three human ovarian cell lines are shown in Table 1. The results showed that SW IV-52s had no cytotoxicity in these two cell lines, whereas SW III-123 showed potent cytotoxicity, suggesting that sigma-2 moiety of SW III-123 delivers the SMC moiety into SMC-insensitive cell lines.

In order to study if the entry of SW III-123 into SKOV-3 cells is mediated by sigma- 2 receptors, we examined whether SW III-123 can block internalisation of SW 120, a fluorescent sigma-2 probe, into cells. SKOV-3 cells were pre-treated with SW 43, SW IV-52s or SW III-123 for $30 \mathrm{~min}$, and then incubated with SW 120 for another $30 \mathrm{~min}$. Internalisation of SW $\mathbf{1 2 0}$ was analysed by flow cytometer. The results showed that SW 43 and SW III-123 blocked the internalisation of SW $\mathbf{1 2 0}$ by $40 \%$ and 57\%, respectively, whereas SW IV-52s did not block the internalisation (Figure 2D). The data suggest that the sigma-2 ligand delivers SMC into the cells, in fairly large part, through sigma-2 receptor-mediated mechanism.

SW IV-52s and SW III-123, but not SW 43, rapidly degraded cIAP1 and cIAP2. In order to study the mechanisms of cell killing by SW III-123, we studied effects of this compound on protein levels of IAPs. SKOV-3 cells were treated with $0,1,3$ and $10 \mu \mathrm{M}$ of SW 43, SW IV-52s or SW III-123 for $24 \mathrm{~h}$. Western blot data showed that SW IV-52s and SW III-123 markedly decreased cIAP1 and cIAP2 protein levels in a dose-dependent manner (Figure 3A). SW IV-52s and SW III-123 slightly decreased XIAP expression as the drug concentration increased. SW 43 did not have any effect on cIAP1, cIAP2 or XIAP protein levels. We also treated SKOV-3 cells with $3 \mu \mathrm{M}$ of SW 43, SW IV-52s or SW III123 for $0,0.5,2,6$ and $24 \mathrm{~h}$. The western blot results showed that SW IV-52s and SW III-123, but not SW 43, induced rapid degradation of cIAP1 and cIAP2, which occurred as early as $0.5 \mathrm{~h}$,
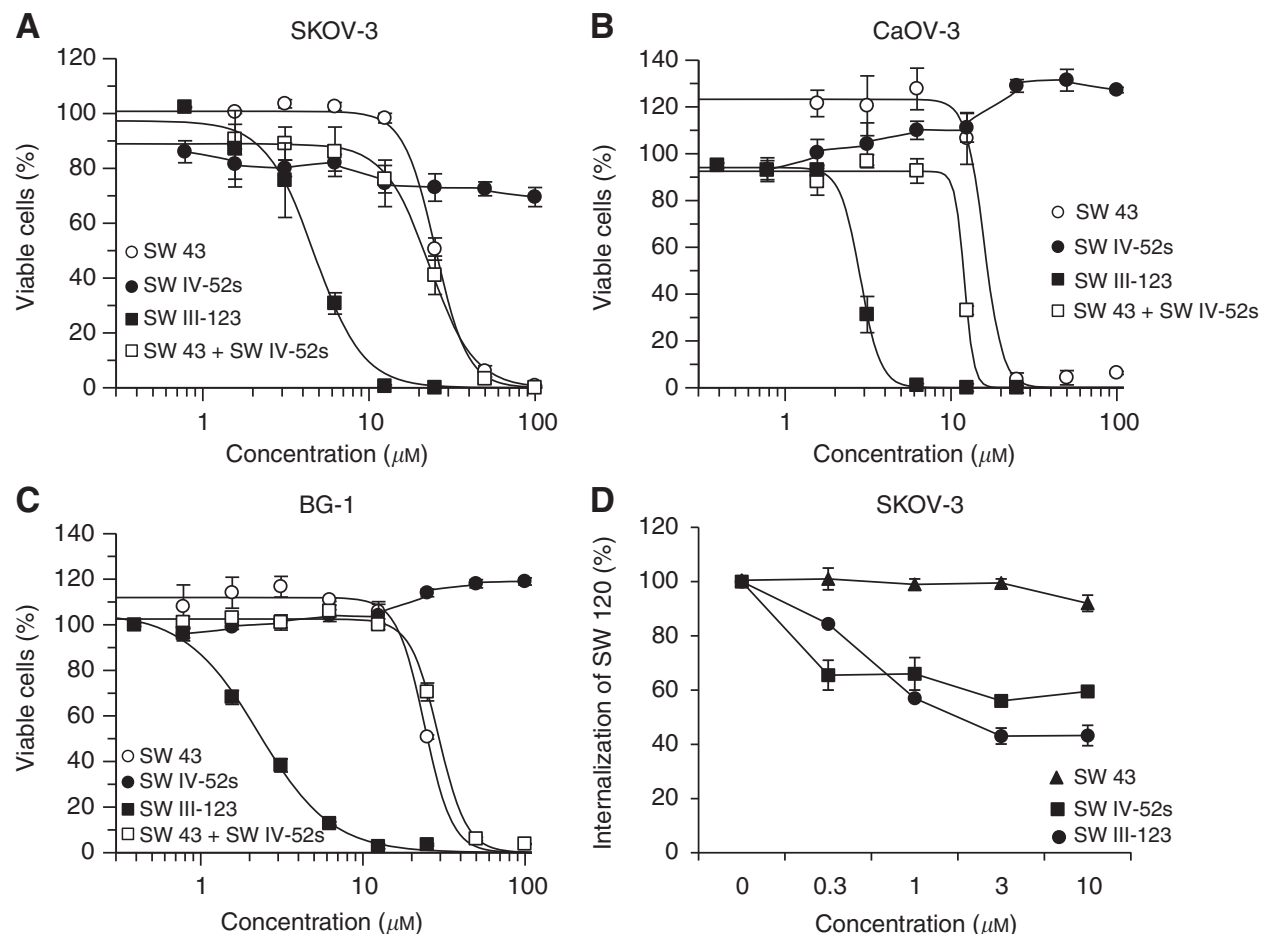

Figure 2. SW III-123 potently induced cell death in ovarian cancer cells. SKOV-3 (A), CaOV-3 (B) or BG-1 (C) cells were treated with increasing

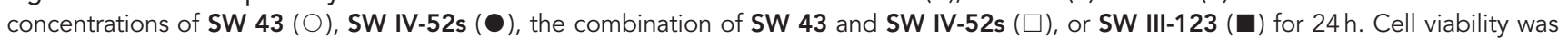
determined by MTS assay. (D) Flow cytometric determination of the internalisation of SW120 in SKOV-3 cells with the blocking compound of SW $43(\square)$, SW IV-52s (A) or SW III-123( ). The bars represent mean \pm s.e.m. in at least three independent experiments.

Table 1. Cytotoxicity of SW 43, SW IV-52s and SW III-123 in human ovarian cancer cells
\begin{tabular}{|l|c|c|c|c|c|c|}
\hline & SKOV-3 & SKOV-3 & CaOV-3 & CaOV-3 & BG-1 & BG-1 \\
\hline Compound & $\mathrm{EC}_{50} \pm$ s.e. $(\mu \mathrm{m}, 24 \mathrm{~h})$ & $\mathrm{EC}_{50} \pm$ s.e. $(\mu \mathrm{m}, 48 \mathrm{~h})$ & $\mathrm{EC}_{50} \pm$ s.e. $(\mu \mathrm{m}, 24 \mathrm{~h})$ & $\mathrm{EC}_{50} \pm$ s.e. $(\mu \mathrm{m}, 48 \mathrm{~h})$ & $\mathrm{EC}_{50} \pm$ s.e. $(\mu \mathrm{m}, 24 \mathrm{~h})$ & $\mathrm{EC}_{50} \pm$ s.e. $(\mu \mathrm{m}, 48 \mathrm{~h})$ \\
\hline SW $\mathbf{4 3}$ & $25.2 \pm 0.7$ & $19.7 \pm 0.8$ & $15.9 \pm 1.1$ & $14.0 \pm 0.5$ & $24.0 \pm 0.9$ & $24.1 \pm 2.1$ \\
\hline SW IV-52s & $>100$ & $0.7 \pm 0.1$ & $>100$ & $>100$ & $>100$ & $>100$ \\
\hline SW III-123 & $4.0 \pm 0.6$ & $1.4 \pm 0.3$ & $2.8 \pm 0.1$ & $1.3 \pm 0.1$ & $2.3 \pm 0.1$ & $1.3 \pm 0.1$ \\
\hline
\end{tabular}


the earliest time point tested after drug treatment. In contrast, none of the three compounds significantly affected XIAP protein levels at any time point. The data suggest that the sigma-2 ligand moiety of SW III-123 does not have a role either in cIAP1/2 degradation or its downstream signalling, and it functions as a drug delivery agent. The SW IV-52s moiety of SW III-123 is responsible for cIAP1/2 degradation and subsequent cell killing mechanisms.

SW IV-52s and SW III-123, but not SW 43, cleaved pro-caspase-8, -9 and -3. XIAP has been shown to be a potent inhibitor of caspase- 9 and caspase- 3 . Both cIAP1 and cIAP2 are implicated in suppression of caspase- 8 activation during $\mathrm{TNF} \alpha$ signalling (Deveraux et al, 1998; Wang et al, 1998). Therefore, we studied if SW IV-52s or SW III-123 induced caspase-8, -9 and -3 activation by western blot analysis. The data showed that SW IV-52s and SW III-123, but not SW43, triggered pro-caspase-8, -9 and -3 cleavage in a dose-dependent manner after 24-h treatment (Figure $3 \mathrm{~A}$ ). In all, $3 \mu \mathrm{M}$ of SW IV-52s or SW III-123, but not SW 43, induced pro-caspase-8, -9 and -3 cleavage in a timedependent manner (Figure 3B). These data suggest that SW IV-52s and SW III-123 activated both intrinsic and extrinsic apoptotic pathways.

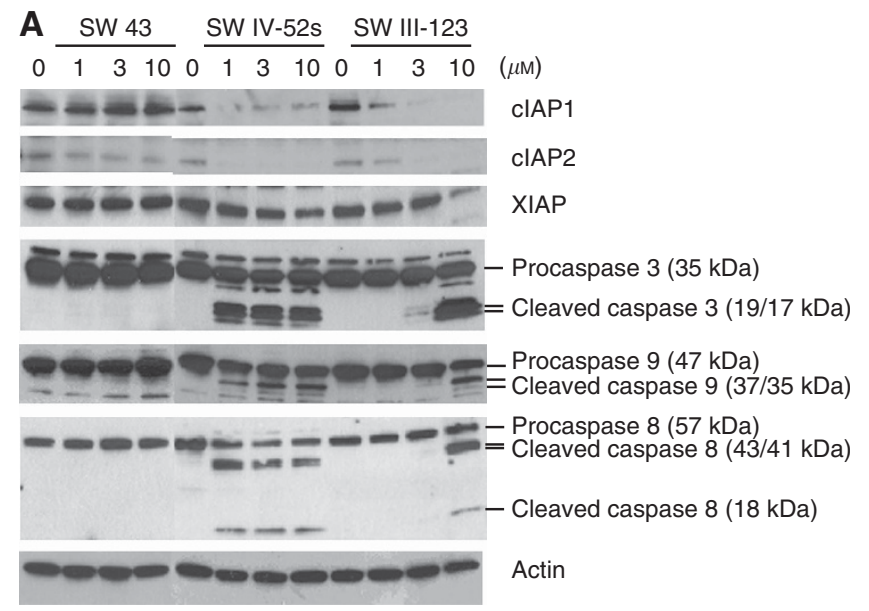

B SW 43 SW IV-52s SW III-123

$0 \longdiv { 0 . 5 2 6 2 4 } \overline { 5 . 0 2 6 2 4 } \overline { 0 . 5 2 6 2 4 }$ (h)

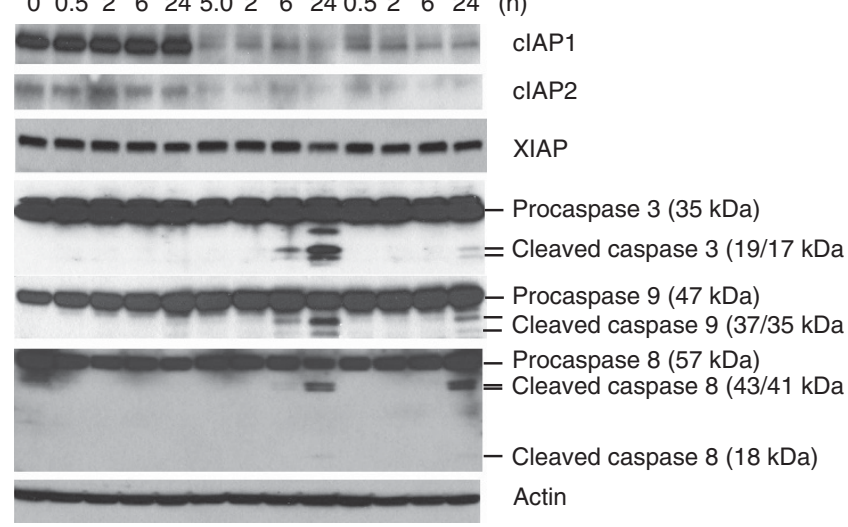

Figure 3. SW IV-52s and SW III-123 rapidly degraded CIAP1 and CIAP2 and cleaved pro-caspase-8, -9 , and -3. (A) SKOV-3 cells were treated with $0,1,3$ and $10 \mu \mathrm{M}$ SW 43, SW IV-52s or SW III-123 for $24 \mathrm{~h}$. The whole-cell lysates were analysed by western blot. (B) SKOV-3 cells were treated with $3 \mu \mathrm{M}$ of SW 43, SW IV-52s or SW III-123 for indicated time. The whole-cell lysates were analysed by western blot.
SW IV-52s and SW III-123, but not SW 43, induced NF- $\kappa$ B activation and TNF $\alpha$-dependent apoptosis. cIAP1 and CIAP2 were originally identified by their association with TNFR2 via TRAF1 and TRAF2 (Rothe et al, 1995; Uren et al, 1996). It has been suggested that degradation of cIAP1 and cIAP2 by SMC activates NF- $\kappa \mathrm{B}$ pathway and induces production of $\mathrm{TNF} \alpha$, a target of NF- $\kappa$ B transcription factors. Therefore, we examined if SW IV-52s or SW III-123 induced NF- $\kappa$ B activation in SKOV-3 cells. Western blot results showed that SW IV-52s and SW III-123, but not SW 43, induced phosphorylation of NF- $\kappa$ B p65 in a dosedependent manner after 24 -h treatment (Figure $4 \mathrm{~A}$ ). In all, $3 \mu \mathrm{M}$ of SW IV-52s or SW III-123 induced phosphorylation of NF- $\kappa$ B p65 in a time-dependent manner (Figure 4B). Phosphorylation of NF- $\kappa$ B p65 occurred as early as 5 min after treatment with SW III-123 (Supplementary Figure 2). These data suggest that canonical NF- $\kappa$ B signalling pathway is activated. The data also showed that SW IV-52s and SW III-123, but not SW 43, induced $\mathrm{NF}-\kappa \mathrm{B}$-inducing kinase (NIK) accumulation in a dose-dependent manner after 24 -h treatment. In total, $3 \mu \mathrm{M}$ of SW IV-52s or SW III-123 significantly increased NIK protein level (Figure 4B) in a time-dependent manner. The results suggest that noncanonical $\mathrm{NF}-\kappa \mathrm{B}$ signalling pathway is activated.

In order to examine if the cell death induced by SW IV-52s or SW III-123 is TNF $\alpha$ dependent, we measured caspase-3 activity in a cell-based assay in the presence or absence of TNF $\alpha$ antibody. SKOV-3 cells were pre-treated with or without $2 \mu \mathrm{g} \mathrm{ml}^{-1} \mathrm{TNF} \alpha$ antibody for $1 \mathrm{~h}$, and then treated with $3 \mu \mathrm{M}$ SW IV-52s, SW 43 or
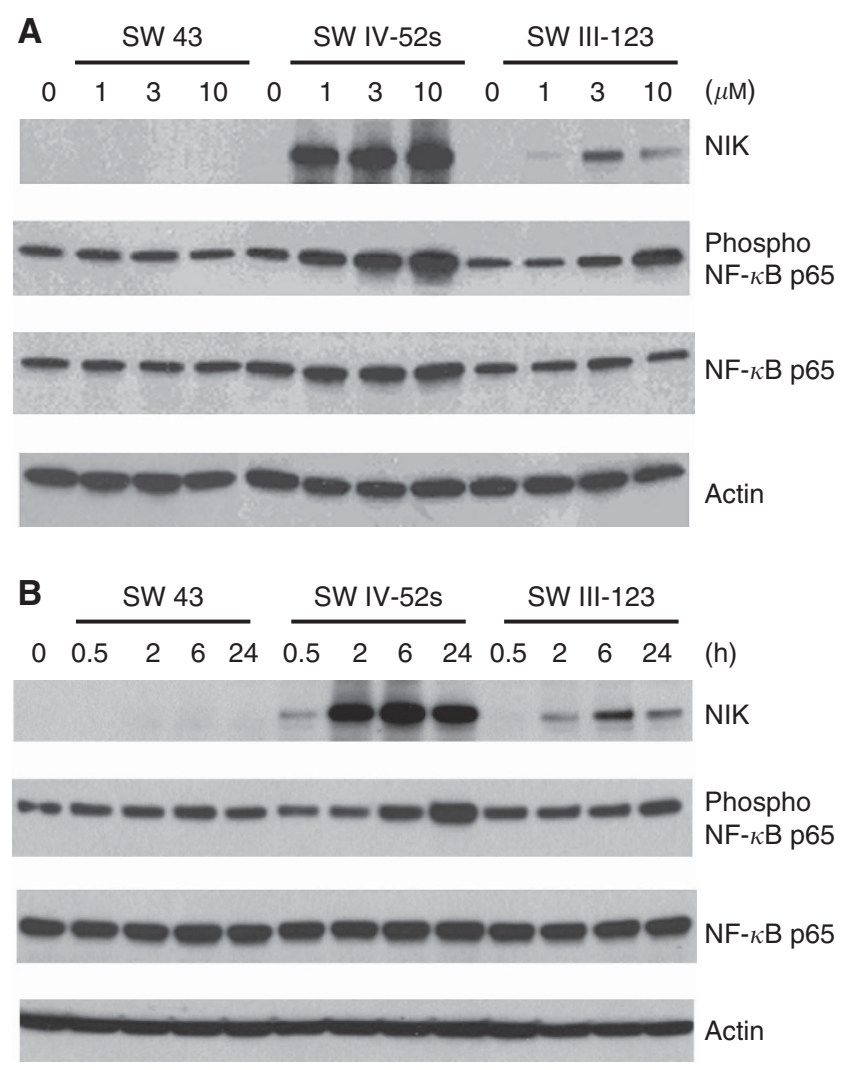

Figure 4. SW IV-52s and SW III-123 induced NF- $\kappa$ B activation. (A) SKOV-3 cells were treated with 0, 1, 3 and $10 \mu \mathrm{M}$ SW 43, SW IV-52s or SW III-123 for $24 \mathrm{~h}$. The whole-cell lysates were analysed by western blot. (B) SKOV-3 cells were treated with $3 \mu \mathrm{M}$ of SW 43, SW IV-52s or SW III-123 for indicated time. The whole-cell lysates were analysed by western blot. 
SW III-123 for $24 \mathrm{~h}$. The cells were assayed for caspase-3 activity. The data showed that SW IV-52s and SW III-123, but not SW 43 , induced caspase- 3 activity, and TNF $\alpha$ antibody markedly blocked caspase- 3 activation induced by either compound (Figure $5 \mathrm{~A}$ ). We also performed MTS viability assay in the presence or absence of $\mathrm{TNF} \alpha$ antibody. We showed that TNF $\alpha$ antibody significantly blocked cell death induced by 3 or $10 \mu \mathrm{M}$ SW IV-52s (Figure 5C) or by $3 \mu \mathrm{M}$ SW III-123 (Figure 5D). These data suggest that SW IV52s and SW III-123 induced TNF $\alpha$-dependent apoptosis in SKOV-3 cells.

$\mathrm{TNF} \alpha$ antibody blocking experiments were also performed in SMC-insensitive ovarian cell lines, CaOV-3 and BG-1. We have shown that SW III-123 induced caspase-3 activation and cell death in these two cell lines. However, unlike in SKOV-3 cells, TNF $\alpha$ antibody did not block SW III-123 induced caspase-3 activation
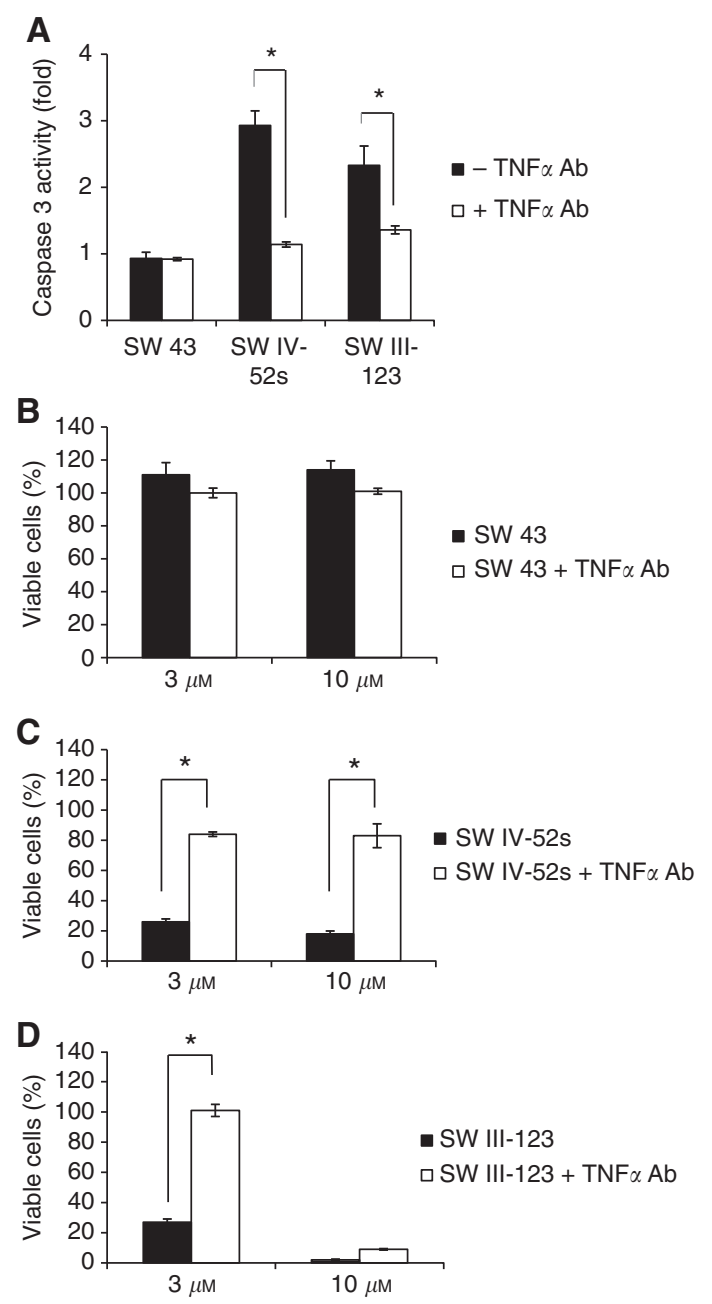

Figure 5. SW IV-52s and SW III-123 induced TNF $\alpha$-dependent apoptosis. (A) SKOV-3 cells were pre-treated with or without $2 \mu \mathrm{g} \mathrm{ml}^{-1}$ TNF $\alpha$ antibody for $1 \mathrm{~h}$, and then treated with $3 \mu \mathrm{M}$ SW IV-52s, SW 43 or SW III-123 for $24 \mathrm{~h}$. The cells were assayed for caspase 3 activity. (B-D) SKOV-3 cells were pre-treated with or without $2 \mu \mathrm{g} \mathrm{ml}^{-1} \mathrm{TNF} \alpha$ antibody for $1 \mathrm{~h}$, and then treated with 3 or $10 \mu \mathrm{M}$ SW 43 (B), SW IV-52s (C) or SW III-123 (D) for $48 \mathrm{~h}$. Viability of cells was determined by MTS assay. The representative data from three independent experiments are shown. ${ }^{\star} P<0.05$. and cell death in CaOV-3 and BG-1 cells (Supplementary Figures 3 and 4), suggesting that SW III-123 induced TNF $\alpha$-independent cell death in SMC-insensitive cell lines.

\section{DISCUSSION}

A major limitation of conventional chemotherapy is toxicity of anticancer drugs to normal tissues. Development of tumourtargeted drug delivery agent represents an important strategy to overcome this problem. By using PET imaging technology, our laboratory has shown that ${ }^{18} \mathrm{~F}$-labelled sigma-2 ligand specifically bind to tumours in mouse models (Tu et al, 2007) and in human clinical studies (Dehdashti et al, 2013). In addition, we have demonstrated that fluorescent sigma-2 ligands are rapidly internalised into cancer cells by endocytosis (Zeng et al, 2007, 2011). These findings led us to propose that sigma-2 ligands can be used as a tumour-targeting drug delivery agent.

In this study, we evaluated this strategy by synthesising a sigma2 ligand-conjugated drug and studying its cell killing mechanisms. We have attached a sigma-2 ligand, SW 43, to an anticancer drug, SW IV-52s to form SW III-123. It was reported that SW IV-52s binds to BIR3 domain of XIAP with high affinity $\left(K_{d}=12 \mathrm{nM}\right)$ and is effective in rescuing XIAP BIR3-mediated inhibition of caspase activity in a cell-free functional assay (Oost et al, 2004; Sun et al, 2008). We showed that SW IV-52s treatment for $24 \mathrm{~h}$ induced minor cytotoxicity $\left(\mathrm{EC}_{50,24 \mathrm{~h}}>100 \mu \mathrm{M}\right)$ in SKOV-3 cells, whereas SW III-123-induced cell death potently $\left(\mathrm{EC}_{50,24 \mathrm{~h}}=4.0 \mu \mathrm{M}\right)$. We also showed that SW IV-52s did not exhibit cytotoxicity in CaOV3 and BG-1 cells, whereas SW III-123 strongly induced cell death in both cell lines (Table 1, Figure 2 and Supplementary Figure 1). The strong cell killing potency of SW III-123 is not due to the additive or synergistic effects of SW 43 and SW IV-52s, because the combination of these two compounds induced much less cytotoxicity than the covalently conjugated compound, SW III-123 (Figure 2A). The data suggest that the sigma-2 ligand (SW 43) moiety of SW III-123 delivers the SMC moiety into cancer cells. Multiple mechanisms may be responsible for the potent cytotoxicity of SW III-123. (1) Compared with SW IV-52s, the intracellular concentration of the SMC moiety of SW III-123 could be increased because of sigma-2 receptor-mediated delivery mechanisms. (2) The subcellular localisation of the SMC moiety of SW III-123 could be different from that of SW IV-52s. Previously, we have shown that a sigma-2 fluorescent probe, SW120, which is an analogue of SW 43, is internalised into cells through endocytotic mechanisms and distributed in mitochondria, endoplasm reticulum and lysosome (Zeng et al, 2011). It is possible that the SW 43 moiety directs the SMC moiety into the SW 43-targeted subcellular organelles where the SMC moiety could interact with IAPs and induce cell death. (3) The SMC moiety of SW III-123 could potentiate the cytotoxicity of the SW $\mathbf{4 3}$ moiety. Figure 2 showed that SW 43 was cytotoxic although at concentrations much higher than SW III-123. The mechanisms of SW 43-elicited cytotoxicity was reported recently. SW 43 induced lysosomal membrane permeabilisation, cathepsin B leakage from lysosome, cellular oxidative stress and caspase-3-independent apoptosis (Hornick et al, 2012). The cytotoxic effects of the SMC moiety could make cells more susceptible to the cytotoxicity of the SW 43 moiety. These possible mechanisms deserve further study.

Previous studies demonstrated that SMCs display cell killing effects only in a subset of cell lines (Sun et al, 2008). Our data showed that SW IV-52s exhibited cytotoxicity in SKOV-3 cells, but not in CaOV-3 or BG-1 cells (Figure 2 and Supplementary Figure 1). However, SW III-123 showed potent cytotoxicity in all of the three cell lines. These data suggest that the sigma-2 ligand can deliver SMC into both SMC-sensitive and SMC-insensitive cell 
lines, expanding the application of SMCs as antitumour agents in more tumour types. We showed that SW III-123 had adequate sigma-2 receptor-binding affinity $\left(K_{i, \sigma 2}=189.90 \mathrm{nM}\right)$, and significantly blocked internalisation of a fluorescent sigma-2 ligand, SW 120, in SKOV3 cells (Figure 2D), indicating that the delivery of SMC into tumour cells by the sigma-2 ligand is mediated by sigma- 2 receptors. Collectively, these results provided the proof-of-concept for sigma-2 receptor-targeted drug delivery.

In order to study the cell death mechanisms induced by SW III123 and SW IV-52s, we first examined if these compounds affect IAP protein levels. We showed that both compounds induced decreases in CIAP1 and cIAP2 protein levels as early as $0.5 \mathrm{~h}$ at $3 \mu \mathrm{M}$, but had little effect on XIAP protein level within 24-h treatment (Figures $3 \mathrm{~A}$ and $\mathrm{B}$ ). It is reported that cIAP1 and cIAP2 are ubiquitin E3 ligases, and SMC triggers auto-ubiquitination and subsequent proteasomal degradation of cIAP1 and cIAP2 (Varfolomeev et al, 2007). Thus, it is possible that SW III-123 and SW IV-52s bind to BIR3 of cIAP1 and CIAP2, and change their conformation, which allows the ubiquitination and subsequent proteasomal degradation. We then studied if SW III-123 and SW IV-52s triggers apoptosis. Western blot results showed that pro-caspase- $8,-9$ and -3 were cleaved (Figures $3 \mathrm{~A}$ and $\mathrm{B}$ ) by the treatment of these compounds, suggesting that both extrinsic and intrinsic apoptotic pathways were activated.

Several studies have demonstrated that SMC induces NF- $\kappa \mathrm{B}$ activation and TNF $\alpha$-dependent cell death (Petersen et al, 2007; Varfolomeev et al, 2007; Vince et al, 2007). NF- $\kappa \mathrm{B}$ family transcription factors regulate the transcription of a vast array of proteins in cell survival, proliferation and inflammatory response (Hayden and Ghosh, 2008; Sun, 2012). The NF- $\kappa \mathrm{B}$ signalling pathways can be classified into canonical and noncanonical pathways. In the canonical $\mathrm{NF}-\kappa \mathrm{B}$ pathway, NF- $\kappa \mathrm{B}$ family members form heterodimers, such as p50/p65 dimer. In unstimulated cells, p50/p65 dimers are sequestered in the cytoplasm by interaction with inhibitors of NF- $\kappa \mathrm{B}(\mathrm{I} \kappa \mathrm{B})$. In the presence of stimuli, I $\kappa \mathrm{B}$ kinase (IKK) phosphorylates $\mathrm{I} \kappa \mathrm{B} \alpha$, triggering its degradation; this leads to the translocation of p50/p65 dimers into the nucleus to regulate transcription. In the noncanonical NF- $\kappa \mathrm{B}$ pathway (Sun, 2012), in the absence of noncanonical NF- $\kappa \mathrm{B}$ inducers, newly synthesised NIK is rapidly bound by TRAF3 and targeted to TRAF-cIAP ubiquitin ligase complex, where cIAP1 and cIAP2 catalyse ubiquitination of NIK through their ubiquitin E 3 ligase activity, targeting NIK for degradation in the proteasome. In cells stimulated by noncanonical signals, NIK is accumulated and activated. NIK activates $\mathrm{IKK} \alpha$, leading to p100 processing to $\mathrm{p} 52$ subunit and nuclear translocation of NF- $\kappa \mathrm{B}$ heterodimer $\mathrm{p} 52 /$ RelB to regulate transcription. In this study, we showed that SW III-123 and SW IV-52s rapidly induced NIK accumulation (Figure 4B), and NIK accumulation peaked after cIAP1 and cIAP2 degradation (Figures $3 \mathrm{~B}$ and $4 \mathrm{~B}$ ). It is likely that degradation of cIAP1 and cIAP2 upon the treatment of SW III-123 and SW IV-52s prevents ubiquitination of NIK by cIAP1 and cIAP2 and its proteasomal degradation, leading to NIK stabilisation and activation of the noncanonical NF- $\kappa \mathrm{B}$ signalling pathway. In addition, we showed that SW III-123 and SW IV-52s induced phosphorylation of NF$\kappa \mathrm{B}$ p65 as early as $5 \mathrm{~min}$ after the treatment (Figures $4 \mathrm{~A}$ and $\mathrm{B}$, and Supplementary Figure 2). It is reported that phosphorylation of NF- $\kappa$ B p65 is required for an optimal activation of canonical NF$\kappa \mathrm{B}$ signalling (Viatour et al, 2005). Thus, our data suggest that canonical NF- $\kappa$ B pathway is activated as well. As shown in Figures 4A and B, SW IV-52s induced more NIK accumulation than SW III-123. SW IV-52s is an optically active compound, containing an (S)-alanyl group, whereas SW III-123 is a racemic compound (i.e., $R / S$-alanyl group). It is possible that only one enantiomer of SW III-123 is biologically active and the racemic SW III-123 is not as effective as SW IV-52s in inducing NIK accumulation. The positive results described in this study led to our devising a new synthetic route for preparing optically pure SW III-123. Future studies with this compound will utilise the optically pure compound.

$\mathrm{TNF} \alpha$ is one of the target genes for NF- $\kappa \mathrm{B}$ transcription factors. We determined if the cell death induced by SW III-123 and SW IV-52s is TNF $\alpha$ dependent. We showed that TNF $\alpha$ antibody markedly inhibited caspase- 3 activation and cell death induced by both compounds (Figures 5A-D) in SKOV-3 cells. These data indicated that NF- $\kappa \mathrm{B}$-induced TNF $\alpha$ is a key player in SW III-123 and SW IV-52s-triggered cell death. The binding of TNF $\alpha$ to TNFR1 has been shown to initiate the extrinsic apoptotic pathway (Aggarwal, 2003). The binding of TNF $\alpha$ to TNFR1 recruits Fasassociated death domain protein, Fas-associated death domain protein and caspase- 8 . Upon recruitment, caspase- 8 is activated by self-cleavage, and then activates caspase-3. It is possible that SW III-123 and SW IV-52s triggered caspase- 8 and -3 cleavage (Figure 3 ) through sequential events of activation of NF- $\kappa \mathrm{B}, \mathrm{TNF} \alpha$ production and $\mathrm{TNF} \alpha$-induced extrinsic apoptotic pathway.

Our data showed that TNF $\alpha$ antibody did not block SW III-123 induced caspase- 3 activation and cytotoxicity in SMC-insensitive ovarian cell lines, CaOV-3 and BG-1 (Supplementary Figure 3 and 4), suggesting that SW III-123 induced TNF $\alpha$-independent cell death. The data are consistent with the previous report that SMC does not induce TNF $\alpha$ production in SMC-insensitive cell lines (Vince et al, 2007). It is not clear why some cells are SMC-sensitive and some are not. The molecular mechanisms of SW III-123induced cell death in SMC-insensitive cells deserve further studies. Sigma-2 ligand-conjugated SMC may offer a new class of drugs for treating SMC-insensitive cancer cells. We showed that SW III-123 and SW IV-52s induced caspase-9 cleavage, suggesting that intrinsic apoptotic pathway is activated. One possible mechanism for caspase- 9 activation is that the activated caspase- 8 via extrinsic pathway engages the intrinsic pathway by cleaving the proapoptotic BCL-2 family member BID (BH3 interacting-domain death agonist). It is reported that during extrinsic apoptosis caspase- 8 is enriched on the mitochondrial surface and form native complex with BID in some cell types (Schug et al, 2011). Following extrinsic apoptotic stimuli, active caspase- 8 cleaves BID. The cleaved BID interacts with other BCL-2 family members on the surface of the mitochondria, which results in mitochondrial outer membrane permeabilisation, cytochome c release, apoptosome assembly, caspase- 9 cleavage and subsequent caspase-3 activation. XIAP binds and inhibits caspase-9 through its BIR3 domain (Shiozaki and Shi, 2004), whereas SMCs such as SW III-123 or SW IV-52s have been shown to bind XIAP BIR3 and remove the inhibition of XIAP for caspase-9, thereby promoting apoptosis.

On the basis of our data and the findings in the literature, we propose a model for SW III-123-induced cell death signalling pathways in SMC-sensitive cell lines (Figure 6). SW III-123 is internalised into cells via sigma-2 receptor-mediated endocytosis. Upon entering cells, SW III-123 binds to cIAP1 and cIAP2 in their BIR3 domain and induces rapid degradation of cIAP1 and cIAP2 and accumulation of NIK, which initiates noncanonical $\mathrm{NF}-\kappa \mathrm{B}$ pathway. Canonical NF- $\kappa \mathrm{B}$ signalling is also activated as SW III-123 induced phosphorylation of NF- $\kappa$ B p65 (Figure 4). The activation of NF- $\kappa \mathrm{B}$ transcription factor induces expression of $\mathrm{TNF} \alpha$, which then binds to TNFRs and triggers the extrinsic apoptotic pathway, resulting in caspase- 8 activation and subsequent caspase- 3 activation. Active caspase- 8 in turn triggers the intrinsic apoptotic pathway presumably via cleaving BID on the surface of mitochondria, leading to caspase- 9 and -3 activation. SW III-123 binds to XIAP BIR3, which disrupts interaction of XIAP and caspase- 9 , and thus activates caspase- 9 and caspase- 3 . In summary, SW III-123 delivers SMC into ovarian cancer cells and then binds to IAPs and induces TNF $\alpha$-dependent apoptosis.

Conjugating a sigma-2 ligand to an anticancer drug provides a platform for delivering drugs selectively into tumour cells. The 


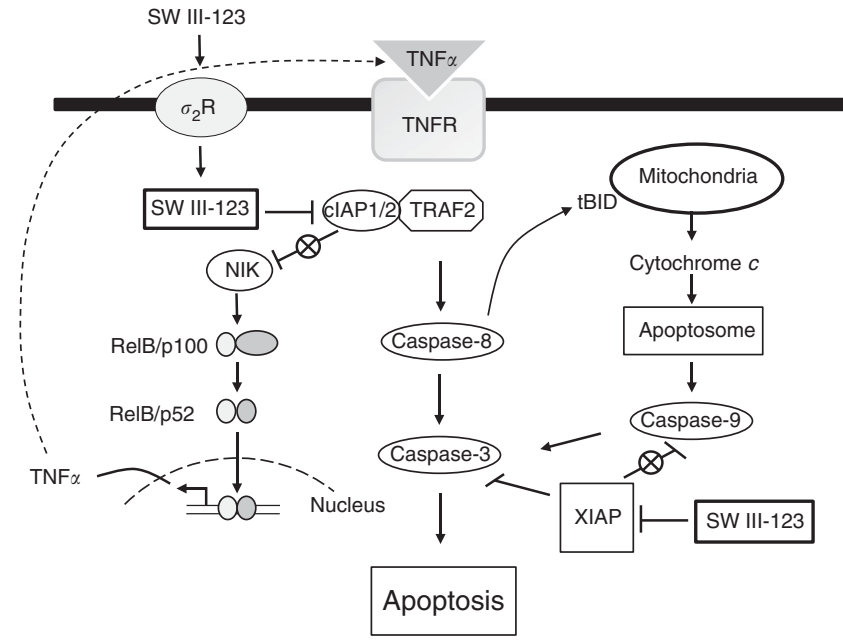

Figure 6. A model for cell death signalling pathways induced by SW III-123. SW III-123 is internalised cells through sigma-2 receptor $(\sigma 2 \mathrm{R})$-mediated endocytosis. SW III-123 degrades CIAP1 and CIAP2, and thus antagonises CIAP1/2-mediated NF- $\kappa$ B-inducing kinase (NIK) degradation, induces nuclear factor (NF)- $\kappa$ B activation and subsequent tumour necrosis factor alpha (TNF $\alpha$ ) production. TNF $\alpha$ binds to TNFR and induces extrinsic and intrinsic apoptotic pathways, leading to caspase-8, -9 and -3 activation. SW III-123 also binds to XIAP, and thus removes the inhibition of XIAP to caspase-9, promoting apoptosis. IAP, inhibitor of apoptosis protein.

sigma-2 receptor ligand may be exploited to carry any cytotoxic drug or drug-loaded nanoparticles to various tumours that overexpress the sigma-2 receptor. Sigma-2 receptor ligand-linked therapeutic agents will likely display reduced off-site toxicity and enhanced potency against tumour cells. These features could lead to improved treatment regimens and cancer patient outcomes.

\section{ACKNOWLEDGEMENTS}

We thank our colleagues Jinbin $\mathrm{Xu}$ and Jinquan Cui for their technical assistance with receptor-binding assays. We thank Justin M Rothfuss for his technical assistance with viability assay and caspase 3 activity assay. We thank the Alvin J Siteman Cancer Center at Washington University School of Medicine and BarnesJewish Hospital in St Louis, MO, USA, for the use of the Siteman Flow Cytometry Core, which provided flow cytometry service. The Siteman Cancer Center is supported in part by NCI Cancer Center Support Grant \#P30 CA91842. We thank the Washington University Mass Spectrometry Resource, which is supported by NIH grant \#2P41 RR000954, for providing mass spectrometry analysis. The current research is supported by $\mathrm{NIH}$ grant CA163764.

\section{REFERENCES}

Aggarwal BB (2003) Signalling pathways of the TNF superfamily: a doubleedged sword. Nat Rev Immunol 3: 745-756.

Bem WT, Thomas GE, Mamone JY, Homan SM, Levy BK, Johnson FE, Coscia CJ (1991) Overexpression of sigma receptors in nonneural human tumors. Cancer Res 51: 6558-6562.

Dehdashti F, Laforest R, Gao F, Shoghi SI, Aft RL, Nussenbaum B, Kreisel FH, Bartlett NL, Cashen A, Wagner-Johnson N, Mach RH (2013) Assessment of cellular proliferation in tumors by positron emission tomography using $\left[{ }^{18}\right.$ F]ISO-1. J Nucl Med 53: 350-357.

Deveraux QL, Roy N, Stennicke HR, Van Arsdale T, Zhou Q, Srinivasula SM, Alnemri ES, Salvesen GS, Reed JC (1998) IAPs block apoptotic events induced by caspase- 8 and cytochrome $\mathrm{c}$ by direct inhibition of distinct caspases. EMBO J 17: 2215-2223.

Dinh P, Harnett P, Piccart-Gebhart MJ, Awada A (2008) New therapies for ovarian cancer: cytotoxics and molecularly targeted agents. Crit Rev Oncol Hematol 67: 103-112.

Du C, Fang M, Li Y, Li L, Wang X (2000) Smac, a mitochondrial protein that promotes cytochrome c-dependent caspase activation by eliminating IAP inhibition. Cell 102: 33-42.

Gyrd-Hansen M, Meier P (2010) IAPs: from caspase inhibitors to modulators of NF-kappaB, inflammation and cancer. Nat Rev Cancer 10: 561-574.

Hayden MS, Ghosh S (2008) Shared principles in NF-kappaB signaling. Cell 132: 344-362.

Hornick JR, Vangveravong S, Spitzer D, Abate C, Berardi F, Goedegebuure P, Mach RH, Hawkins WG (2012) Lysosomal membrane permeabilization is an early event in Sigma-2 receptor ligand mediated cell death in pancreatic cancer. J Exp Clin Cancer Res 31: 41.

Jemal A, Siegel R, Ward E, Hao Y, Xu J, Thun MJ (2009) Cancer statistics, 2009. CA Cancer J Clin 59: 225-249.

Mach RH, Smith CR, al-Nabulsi I, Whirrett BR, Childers SR, Wheeler KT (1997) Sigma 2 receptors as potential biomarkers of proliferation in breast cancer. Cancer Res 57: 156-161.

Oost TK, Sun C, Armstrong RC, Al-Assaad AS, Betz SF, Deckwerth TL, Ding H, Elmore SW, Meadows RP, Olejniczak ET, Oleksijew A, Oltersdorf T, Rosenberg SH, Shoemaker AR, Tomaselli KJ, Zou H, Fesik SW (2004) Discovery of potent antagonists of the antiapoptotic protein XIAP for the treatment of cancer. J Med Chem 47: 4417-4426.

Petersen SL, Wang L, Yalcin-Chin A, Li L, Peyton M, Minna J, Harran P, Wang X (2007) Autocrine TNFalpha signaling renders human cancer cells susceptible to Smac-mimetic-induced apoptosis. Cancer Cell 12: 445-456.

Petrucci E, Pasquini L, Bernabei M, Saulle E, Biffoni M, Accarpio F, Sibio S, Di Giorgio A, Di Donato V, Casorelli A, Benedetti-Panici P, Testa U (2012) A small molecule SMAC mimic LBW242 potentiates TRAIL- and anticancer drug-mediated cell death of ovarian cancer cells. PLoS One 7: e35073.

Petrucci E, Pasquini L, Petronelli A, Saulle E, Mariani G, Riccioni R, Biffoni M, Ferretti G, Benedetti-Panici P, Cognetti F, Scambia G, Humphreys R, Peschle C, Testa U (2007) A small molecule Smac mimic potentiates TRAIL-mediated cell death of ovarian cancer cells. Gynecol Oncol 105: 481-492.

Rothe M, Pan MG, Henzel WJ, Ayres TM, Goeddel DV (1995) The TNFR2-TRAF signaling complex contains two novel proteins related to baculoviral inhibitor of apoptosis proteins. Cell 83: 1243-1252.

Schug ZT, Gonzalvez F, Houtkooper RH, Vaz FM, Gottlieb E (2011) BID is cleaved by caspase- 8 within a native complex on the mitochondrial membrane. Cell Death Differ 18: 538-548.

Shiozaki EN, Shi Y (2004) Caspases, IAPs and Smac/DIABLO: mechanisms from structural biology. Trends Biochem Sci 29: 486-494.

Spitzer D, Simon Jr. PO, Kashiwagi H, Xu J, Zeng C, Vangveravong S, Zhou D, Chang K, McDunn JE, Hornick JR, Goedegebuure P, Hotchkiss RS, Mach RH, Hawkins WG (2012) Use of multifunctional sigma-2 receptor ligand conjugates to trigger cancer-selective cell death signaling. Cancer Res 72: 201-209.

Stordal B, Pavlakis N, Davey R (2007) A systematic review of platinum and taxane resistance from bench to clinic: an inverse relationship. Cancer Treat Rev 33: 688-703.

Sun H, Nikolovska-Coleska Z, Yang CY, Qian D, Lu J, Qiu S, Bai L, Peng Y, Cai Q, Wang S (2008) Design of small-molecule peptidic and nonpeptidic Smac mimetics. Acc Chem Res 41: 1264-1277.

Sun SC (2012) The noncanonical NF-kappaB pathway. Immunol Rev 246: $125-140$.

Torchilin VP (2010) Passive and active drug targeting: drug delivery to tumors as an example. Handb Exp Pharmacol 197: 3-53.

Tu Z, Dence CS, Ponde DE, Jones L, Wheeler KT, Welch MJ, Mach RH (2005) Carbon-11 labeled sigma2 receptor ligands for imaging breast cancer. Nucl Med Biol 32: 423-430.

Tu Z, Xu J, Jones LA, Li S, Dumstorff C, Vangveravong S, Chen DL, Wheeler KT, Welch MJ, Mach RH (2007) Fluorine-18-labeled benzamide analogues for imaging the sigma2 receptor status of solid tumors with positron emission tomography. J Med Chem 50: 3194-3204.

Uren AG, Pakusch M, Hawkins CJ, Puls KL, Vaux DL (1996) Cloning and expression of apoptosis inhibitory protein homologs that function to inhibit apoptosis and/or bind tumor necrosis factor receptor-associated factors. Proc Natl Acad Sci USA 93: 4974-4978. 
Vangveravong S, Xu J, Zeng C, Mach RH (2006) Synthesis of N-substituted 9-azabicyclo[3.3.1]nonan-3alpha-yl carbamate analogs as sigma2 receptor ligands. Bioorg Med Chem 14: 6988-6997.

Varfolomeev E, Blankenship JW, Wayson SM, Fedorova AV, Kayagaki N, Garg P, Zobel K, Dynek JN, Elliott LO, Wallweber HJ, Flygare JA, Fairbrother WJ, Deshayes K, Dixit VM, Vucic D (2007) IAP antagonists induce autoubiquitination of c-IAPs, NF-kappaB activation, and TNFalpha-dependent apoptosis. Cell 131: 669-681.

Viatour P, Merville MP, Bours V, Chariot A (2005) Phosphorylation of NF-kappaB and IkappaB proteins: implications in cancer and inflammation. Trends Biochem Sci 30: 43-52.

Vilner BJ, Bowen WD (1993) Sigma receptor-active neuroleptics are cytotoxic to C6 glioma cells in culture. Eur J Pharmacol 244: 199-201.

Vilner BJ, de Costa BR, Bowen WD (1995) Cytotoxic effects of sigma ligands: sigma receptor-mediated alterations in cellular morphology and viability. J Neurosci 15: 117-134.

Vince JE, Wong WW, Khan N, Feltham R, Chau D, Ahmed AU, Benetatos CA, Chunduru SK, Condon SM, McKinlay M, Brink R, Leverkus M, Tergaonkar V, Schneider P, Callus BA, Koentgen F, Vaux DL, Silke J (2007) IAP antagonists target cIAP1 to induce TNFalpha-dependent apoptosis. Cell 131: 682-693.

Wang CY, Mayo MW, Korneluk RG, Goeddel DV, Baldwin Jr. AS (1998) NF-kappaB antiapoptosis: induction of TRAF1 and TRAF2 and c-IAP1 and c-IAP2 to suppress caspase-8 activation. Science 281: 1680-1683.

Wang S (2011) Design of small-molecule Smac mimetics as IAP antagonists. Curr Top Microbiol Immunol 348: 89-113.

Wheeler KT, Wang LM, Wallen CA, Childers SR, Cline JM, Keng PC, Mach RH (2000) Sigma-2 receptors as a biomarker of proliferation in solid tumours. Br J Cancer 82: 1223-1232.
$\mathrm{Xu}$ J, Tu Z, Jones LA, Vangveravong S, Wheeler KT, Mach RH (2005) $\left[{ }^{3} \mathrm{H}\right] \mathrm{N}$-[4-(3,4-dihydro-6,7-dimethoxyisoquinolin-2(1H)-yl)butyl]-2methoxy-5 -methylbenzamide: a novel sigma-2 receptor probe. Eur $J$ Pharmacol 525: 8-17.

Xu J, Zeng C, Chu W, Pan F, Rothfuss JM, Zhang F, Tu Z, Zhou D, Zeng D, Vangveravong S, Johnston F, Spitzer D, Chang KC, Hotchkiss RS, Hawkins WG, Wheeler KT, Mach RH (2011) Identification of the PGRMC1 protein complex as the putative sigma-2 receptor binding site. Nat Commun 2: 380.

Yang C, Davis JL, Zeng R, Vora P, Su X, Collins LI, Vangveravong S, Mach RH, Piwnica-Worms D, Weilbaecher KN, Faccio R, Novack DV (2013) Antagonism of inhibitor of apoptosis proteins increases bone metastasis via unexpected osteoclast activation. Cancer Discov 3: 212-223.

Zeng C, Vangveravong S, Jones LA, Hyrc K, Chang KC, Xu J, Rothfuss JM, Goldberg MP, Hotchkiss RS, Mach RH (2011) Characterization and evaluation of two novel fluorescent sigma-2 receptor ligands as proliferation probes. Mol Imaging 10: 420-433.

Zeng C, Vangveravong S, Xu J, Chang KC, Hotchkiss RS, Wheeler KT, Shen D, Zhuang ZP, Kung HF, Mach RH (2007) Subcellular localization of sigma-2 receptors in breast cancer cells using two-photon and confocal microscopy. Cancer Res 67: 6708-6716.

This work is published under the standard license to publish agreement. After 12 months the work will become freely available and the license terms will switch to a Creative Commons AttributionNonCommercial-Share Alike 3.0 Unported License.

Supplementary Information accompanies this paper on British Journal of Cancer website (http://www.nature.com/bjc) 